\title{
ACTIVIDADES DE LA SECCIÓN HISPANISTA DEL INSTITUTO DE ESTUDIOS ROMÁNICOS, 2018
}

En el año 2018, la sección hispanista del Instituto de Estudios Románicos continuó la promoción de los estudios filológicos entre estudiantes de escuelas secundarias en la República Checa (realizando presentaciones y ponencias en dichos centros), así como en una colaboración estrecha con el Insituto Cervantes. Esta cooperación se dio en varios niveles, sobre todo en el ámbito cultural (presentaciones de libros, tertulias literarias) y en el área de la educación: los estudiantes participaron en talleres preparados por la biblioteca Carlos Fuentes y en el marco de los estudios didácticos realizaron el curso "Profesor-sombra".

Asimismo, los profesores de la sección se dedicaron a la preparación de nuevos programas dedicados a la didáctica de la lengua española. Como resultado presentaron el programa de grado (Španělský jazyk a literatura se zaměřením na vzdělávání) y el programa de máster (Učitelství španělského jazyka a literatury pro střední školy) al proceso de acreditación que resultó exitoso.

En octubre 2018 se celebró el coloquio „Lenguas en la frontera de culturas", en colaboración con la revista universitaria Svět literatury. Fueron presentadas las ponencias sobre la literatura latinoamericana de Dora Poláková y la doctoranda Alice Lukešová, publicadas más tarde en la revista Svět literatury 60, 2019.

Petr Čermák, director del Instituto de Estudios Románicos, participó en varias conferencias internacionales (p. ej. en VII Jornadas Internacionales de Lingüística Hispánica. Lengua y sociedad en Lisboa) y fue miembro del comité científico de los congresos I Congreso Internacional de Didáctica de la Lengua. El desarrollo de la competencia oral en la Universidad de Salamanca y XVI Complutense Translation Conference / PaCOR 2018 en la Universidad Complutense, Madrid.
Anna Housková publicó el libro Borges infinito [Nekonečný Borges], Praha: Triáda, 2018, primera monografía académica en lengua checa sobre el famoso escritor argentino, que se dedica, principalmente, a su obra ensayística. El libro incluye la bibliografía de las traducciones al checo y de la recepción crítica checa de Borges. La profesora Housková también protagonizó el programa de radio „Knižní pól: Ze své knihovny vybírá hispanistka Anna Housková“, ČRo Vltava, 24 de junio de 2018, publicado en la revista Souvislosti.

Javier González hizo de tutor de dos profesores en prácticas de la Universidad de Alicante, dirigió cursos de actualización para profesores de español en colaboración con el Instituto Cervantes y la Embajada (reconocidos por el Ministerio de Educación checo) y participó con ponencias y clase 0 del castellano en el Día europeo de las lenguas organizado por la Facultad de Filosofía y Letras en el campus Hybernská.

Dana Kratochvílová publicó la monografía Modality in Spanish and Combinations of Modal Meaning. Junto con Dora Poláková organizaron el curso preparativo para los estudiantes interesados en los estudios del español en la facultad.

Dora Poláková participó en el Congreso de la AEELH Mi casa está en la frontera. Caminos de ida y vuelta en la literatura y cultura hispánicas en Vigo y continuó con sus investigaciones en el campo del modernismo hispanoamericano y el género cuentístico. Junto con Dana Kratochvílová y Petr Čermák asistió a la conferencia de hispanistas en Lodz.

\section{por Dora Poláková, Praga (Escrito en español por la autora)}

https://doi.org/10.14712/24647063.2020.15 